\title{
The Potential of Tropical Tannin Rich Browses in Reduction of Enteric Methane
}

\author{
Belete Shenkute Gemeda $^{1 *}$ and Abubeker Hassen ${ }^{2}$ \\ ${ }^{1}$ Department of Animal Science, Ethiopia \\ ${ }^{2}$ Department of Animal and Wildlife Sciences, Pretoria, South Africa
}

*Corresponding author: Belete Shenkute Gemeda, Department of Animal Science, College of Agriculture and Natural Science, P.O.Box: 193, Assela, Ethiopia

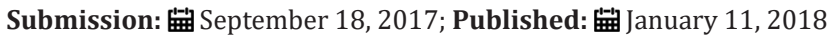

\begin{abstract}
This paper reviewed the effect of tannin on intake, digestibility, fermentation and methane production of various tropical browses. Under communal production system in Africa, ruminants have free access to trees and shrubs throughout the year especially, in dry season. These browse contains high nitrogen in addition to tannins that can suppress rumen methanogenesis. Hydrolysable and condensed tannins and their extracts have been shown to decrease methane $\left(\mathrm{CH}_{4}\right)$ production under both in vivo and in vitro conditions. The molecular weight is a key factor for its effect on digestive enzymes and microbes in the rumen. Low molecular weight tannins could be more effective inhibitors of microbes, including methanogens, compared with high molecular weight tannins. Consumption of low to moderate concentrations of tannins did not affect voluntary feed intake, while high tannin concentrations resulted in reduced intake. The effect of tannins on protein degradation is a reduction in the immediately degradable fraction and fractional rate of degradation. Thus a systematic evaluation is needed to determine optimum levels of supplementation in a mixed diet in order to attain a maximal depressing effect on enteric $\mathrm{CH}_{4}$ production with a minimal detrimental effect on rumen fermentation of poor quality roughage based diet Therefore, more in vivo studies for tannin rich plants and their extract should be conducted with hydrolysable tannins since they appear to be more promising.
\end{abstract}

Keywords: Browses; Digestibility; Intake; Methane; Reduction

Abbreviations: $\mathrm{CH}_{4}$ : Methane; GHG: Greenhouse Gasses; $\mathrm{CO}_{2}$ :Carbon Dioxide; $\mathrm{N}_{2} \mathrm{O}$ : Nitrous Oxide; Gt: Giga Tone; $\mathrm{CO}_{2}$-eq: Carbon Dioxide Equivalent

\section{Introduction}

The global human population is estimated to be 9.15 billion in 2050 and most of the increase is expected to be in developing countries [1]. This growth was driven by the rapidly increasing demand for livestock products, coupled with population growth, urbanization and increasing incomes. Despite this, the animal product consumption level is still lower in developing countries than in developed countries [2], indicating substantial need for expansion of livestock production. In smallholder crop-livestock, agro-pastoral, and pastoral livestock systems of tropical Africa, livestock production is one of the options that could increase income and sustain the livelihoods of farmers. Above all, ruminants are capable of converting plant fibres (structural carbohydrates), which constitute the planet's most renewable abundant resource, into useful end products (high-quality protein, fibre, etc). Despite such contributions, currently livestock production faces climate change challenges globally, in addition to feed shortages in the developing and least developing countries.

The primary problem of livestock production in Africa is low quality and quantity of feed throughout most of the year. In this region, livestock production is dominated by smallholder farmers with communal and small-sized private grazing areas [3]. Such areas are characterized by an inadequate supply of feed, which is low in quality with low nitrogen and high fibre contents. Similarly, crop residues, which are other major sources of feed, are characterized by low nitrogen concentration, high fibre and low digestibility. Thus, these materials may be not sufficient to meet the maintenance and production nutritional requirements of the animal, which may increase the environmental footprint of livestock production from the system [4]. Therefore, supplementation with nitrogen and energy is essential to improve palatability, intake, and rumen fermentation and improve animal production [5].

In current decades, the impact of global warming and continued uncontrolled release of greenhouse gasses (GHG) have negatively influenced livestock production and food security [6]. Livestock production contributes a significant amount of GHG emissions worldwide, generating carbon dioxide $\left(\mathrm{CO}_{2}\right)$, methane and nitrous oxide $\left(\mathrm{N}_{2} \mathrm{O}\right)$ throughout the production cycle. Livestock contributes to total GHG emissions through land use and land-use change $(2.5 \mathrm{Gt}$ $\mathrm{CO}_{2}$-eq); feed production, except $\mathrm{C}$ released from soil (0.4Gt CO2eq); enteric fermentation from ruminants $\left(\mathrm{CH}_{4}\right)$ and on-farm fossil fuel use $\left(\mathrm{CO}_{2}\right)$ (1.9Gt $\mathrm{CO} 2$-eq); manure management $\left(2.2 \mathrm{Gt} \mathrm{CO}_{2}\right.$ - 
eq); and processing and international transport (0.03Gt $\mathrm{CO}_{2}$-eq) [7]. The contribution of livestock by respiration accounts for only a small part of GHG emissions, but other livestock-related activities play a much greater role. It is reported that the rate of increase in GHG emission has differed over time, most noticeably with global atmospheric $\mathrm{CH}_{4}$ concentrations appearing to stabilize between 1999 and 2007; however, $\mathrm{CH}_{4}$ concentrations are again rising [8]. In the developed world, they are expected to decline due to increased productivity, coupled with declining number of ruminants [7]. However, in the developing world and from the African continent they are expected to rise due to increases in animal numbers [9].

One important strategy for improving fibre fermentation in ruminants is to supplement poor quality diets with browses rich in nitrogen [10]. Tropical browses contain reasonably high nitrogen and low fibre content, and can be good candidates for supplementing poor quality feeds. However, it contains tannins in a variable amount as a means of its defence mechanism against herbivores. Several studies have indicated that tannins have antimethanogenic activity, either by direct inhibition of methanogens or indirectly through inhibition of protozoa [11-13]. Interestingly, tannins can be beneficial or detrimental to ruminants depending on its type, amount consumed, structure and molecular weight, and the physiology of the animal. It has been reported that consumption of low or moderate concentrations of tannin does not affect voluntary feed intake, but can suppress $\mathrm{CH}_{4}$ production. Tannins vary in its structure depending on; source, type and level that further variably influence methanogenesis, fermentation and rumen function [14]. Thus, tropical tannifferous browses in different ecologies have to be characterized for its effect of tannins on fermentation and methanogensis. With such available knowledge, optimal utilization of tannin containing browses for different ruminant production systems can be recommended. Moreover, supplementation of tannin containing browses can be regarded as a way forward to increase poor quality feed utilization and reducing enteric $\mathrm{CH}_{4}$ emission [15]. In this paper, various literature wherein effects of tannins have been evaluated are presented, and their potential for mitigating methane from ruminant livestock is discussed.

\section{Discussion}

\section{Ruminal carbohydrate fermentation and $\mathrm{CH}_{4}$ production}

Rumen environment: The rumen, the main site of enteric $\mathrm{CH}_{4}$ production, contains a diverse and dense microbial population living symbiotically, and plays a significant role in the feed digestive processes of ruminant animals [16]. The rumen has a stable and dynamic environment, which is well established to perform the function of bioconversion of feed into rumen fermentation products [17]. The microbial ecosystem comprises numerous populations of bacteria, anaerobic fungi, ciliate protozoa [17-19] These microbes play a crucial role through their involvement in fibre fermentation, either through direct attachment to feed particles and secreting fibre fermenting enzymes or indirectly by enhancing the attachment of other microbes to increase fibre digestion. According to Niwinski [20], rumen microbes have highly complicated and diverse synergistic and antagonistic relationships among the classes of microbes. For example, populations of fibrolytic bacteria producing $\mathrm{H}_{2}$ are positively correlated to methanogens due to the inter-species hydrogen-transfer relationship in the rumen [21]. During this process, carbohydrates are fermented to produce volatile fatty acids (VFAs), energy, $\mathrm{CH}_{4}, \mathrm{CO}_{2}$ and heat. $\mathrm{CO}_{2}$ and $\mathrm{CH}_{4}$ are eliminated via the nose and mouth by belching and eructation, leading to loss of energy. The relationship between fermenting species and H-utilizing microbes normally exists as a symbiotic function, which is called 'interspecies hydrogen transfer' [22]. Thus, synthesis of $\mathrm{CH}_{4}$ occurs because of the exchange of metabolites between $\mathrm{H}$-producing microbes such as fibrolytic fungi and bacteria and H-consuming microbes such as methanogens [23]. This continuous production and removal of $\mathrm{H}$ facilitates continuous fibre fermentation in the rumen.

Methane production and associated loss of feed energy: Methane is produced by methanogenic archaea as a by-product of anaerobic fermentation of feed in the rumen. This production causes a significant loss of dietary energy [24]. With normal rumen functioning, methanogenesis is essential for optimal rumen performance, because it prevents $\mathrm{H}$ accumulation that can lead to inhibition of dehydrogens involved in the oxidation of reduced co-factors [21]. Fermentation is an oxidative process in which cofactors such as NADH, FADH, NADPH have to be reduced to NAD+, $\mathrm{NADP}+, \mathrm{FAD}+$ through dehydrogenation reactions by releasing $\mathrm{H}$ in the rumen [21]. As soon as reduced co-factors are produced, $\mathrm{H}$ is used by methanogens to reduce $\mathrm{CO}_{2}$ by forming $\mathrm{CH}_{4}$ according to the following equation:

$$
\mathrm{CO}_{2}+4 \mathrm{H}_{2}=\mathrm{CH}_{4}+2 \mathrm{H}_{2} \mathrm{O}----------------- \text { equation (1) }
$$

Methane is a source of feed energyloss to the animal [25]. It represents on average $10 \%$ of gross energy (GE) intake, which ranges from $7 \%$ to $17 \%$ of gross energy (GE), depending on diet characteristics [26,27]. Methane contains $892.6 \mathrm{KJMol}-1$ energy at $25^{\circ} \mathrm{C}$ and $101.3 \mathrm{kPa}$ [28]. This amount of gross energy is lost instead of contributing to the total supply of energy for metabolism in the ruminant. In tropical ruminant production systems, this value might be higher due to poor-quality diets, which are often deficient in vital nutrients for optimal microbial growth in the rumen.

Relationship between chemical composition, digestion and $\mathbf{C H}_{4}$ production: The amount of $\mathrm{H}$ produced during fermentation of feed is highly dependent on the quality of diet and the proportion of the different types of rumen microbes, because the pathways for VFA production differ in terms of $\mathrm{H}$ input/output. Other factors, such as $\mathrm{pH}$, feeding strategy, animal species and environmental factors, also determine $\mathrm{CH}_{4}$ production in the rumen [29].

Feed intake is a critical factor for improving productivity, increasing feed efficiency and decreasing $\mathrm{CH}_{4}$ production in ruminant feeds. Dietary NDF concentration is one of the important regulators of feed intake that determine energy yield, digesta flow and the so-called fill-limitation mechanism [16]. Increased intake of poor-quality feeds has little effect on $\mathrm{CH}_{4}$ production, while increasing the digestibility of feed results in a depression in the amount of $\mathrm{CH}_{4}$ produced per unit of feed consumed [30]. As the 
digestibility of a feed increases, the amount of energy available to the animal rises, therefore the $\mathrm{CH}_{4}$ emitted per $\mathrm{kg}$ of production, for example weight gain, decreases. Thus, increased digestibility of diets often means fewer $\mathrm{CH}_{4}$ emissions per unit of production. However, with digestibility above $72 \%$, the increasing effect on the emissions becomes marginal. Broderick compared ryegrass silage with alfalfa silage as part of a total mixed ration of iso-nitrogenous and similar amount of NDF and reported that feed intake and milk production were much higher with the alfalfa silage diet, but with a relatively lower feed efficiency. This indicated that the major challenge with forage-based diets is improving diet quality in order to reduce $\mathrm{CH} 4$, as the correlation between forage quality and $\mathrm{CH}_{4}$ emissions is sometimes low [15,31-33].

In extensive grazing systems, where diets are of low to moderate digestibility, increased dry matter intake (DMI) is associated with increased $\mathrm{CH}_{4}$ production [32]. In such conditions, $\mathrm{CH}_{4}$ released per unit of additional intake is more than the $\mathrm{CH}_{4}$ produced per unit intake of highly digestible feeds. On the contrary, $\mathrm{CH}_{4}$ production per unit metabolizable energy (ME) intake is lowest for highenergy diets. In addition, small changes in energy intake result in corresponding minor changes in $\mathrm{CH}_{4}$ output and large changes in animal performance. Many studies have attempted to determine the relationship between $\mathrm{CH}_{4}$ production and GE intake using empirical prediction equations. These equations, however, do not fully describe changes in composition of the diet and have limited use in estimating the impact of varying nutritional strategies on $\mathrm{CH}_{4}$ emissions [16]. These challenges can be addressed by expressing CH4 energy loss on a DE basis or per unit of animal product, which better reflects forage quality and other mitigation practices, such as grain or fat inclusion in ruminant diets [16].

\section{Rumen modulators used to reduce $\mathrm{CH} 4$ production}

Enteric $\mathrm{CH}_{4}$ production depends primarily on quantity and quality of the diet [15,33-36], the nature of fermented carbohydrates [34,35], concentration of NDF and ADF [36], the acetate to propionate ratio of fermented feeds [37] and the type and harvest stage of forage consumed by the animal [38]. If rumen fermentation patterns shift from acetate to more propionate in the total VFA production, net hydrogen and $\mathrm{CH}_{4}$ production will be reduced. Thus, any viable strategy has to result in one or more of these goals:

i. Reduction of hydrogen production that should be achieved without impairing feed digestion.

ii. Stimulation of hydrogen utilization towards pathways that produce other end products beneficial for the animal such as propionate production.

iii. Inhibition of the methanogenic activity and its numbers. When using this strategy, it is important to suppress $\mathrm{CH}_{4}$ producing micro-biota activities and proliferation without limiting rumen function.

Increased concentrate proportions in ruminant rations are generally associated with a reduction in $\mathrm{CH}_{4}$ emission per unit of feed intake and per unit of animal product $[39,40]$. For example, fermentation of a diet with $70 \%$ concentrate produced a $59 \%$ increase in ruminal propionate concentration and a $44 \%$ drop in the A: Pratio in lactating dairy cows compared with a $50 \%$ concentrate diet [41]. Bannink et al. [42] also reported that the fermentation of sugars and starch would shift rumen fermentation toward the production of propionate. In a relationship proposed by Sauvant et al. [43], methane yield and A: P ratio in ruminal fluid showed a quadratic relationship in 23 experiments. These findings generally showed that higher inclusions of grain or starch content in ruminant diets lowered enteric $\mathrm{CH}_{4}$ production.

However, in most tropical and sub-tropical livestock production systems, ruminants receive only small quantities of concentrates owing to direct competition with human and monogastric animals and high costs of concentrates. In addition, previous research suggested that increased forage quality would reduce $\mathrm{CH}_{4}$ emissions per unit of weight gain $[44,45]$ or per unit of animal product [46], owing to improvement in animal productivity. Many research reports have also shown potential for direct inhibition of methanogens through immunization of animals, and the use of plant polyphenols, bacteriophages and bacteriocins $[14,47,48]$. Currently, indirect methods of redirecting hydrogen are also receiving a lot of scientific attention. These methods include the use of ionophores such as monensin, fatty acids/lipids, organic acids [49], nitrate and sulfate supplementation. Some of these strategies are discussed below in the context of ruminants consuming high forage diets.

\section{Supplementation with plant tannins}

Tannins are compounds with high molecular weight that have the capacity to form reversible and irreversible complexes with proteins, polysaccharides (cellulose, hemicellulose, and pectin), alkaloids, nucleic acids and minerals [33,50]). They are synthesized naturally in nutritionally important forage trees, shrubs and legumes, fruits, cereals and grains in variable amounts. Tannins are categorized broadly into condensed or hydrolyzed tannins. Hydrolysable tannins are made up of a carbohydrate core whose hydroxyl groups are esterified with phenolic acids. Condensed tannins (pro-antho-cyanidins) are non-branched polymers of flavonoid units and usually have a higher molecular weight relative to hydrolysable tannins [51]. Hydrolysable tannins can be hydrolyzed and utilized by rumen microbes, while condensed tannins are resistant to hydrolysis.

Effects of tannins on methanogenesis: Hydrolysable and condensed tannins and their extracts have been shown to decrease $\mathrm{CH}_{4}$ production under both in vivo and in vitro conditions $[12,14,40,52,53]$. The molecular weight is a key factor for its effect on digestive enzymes and microbes in the rumen. Low molecular weight tannins could be more effective inhibitors of microbes, including methanogens, compared with high molecular weight tannins $[14,52,54]$. This is because low molecular weight tannins form strong complexes with microbial enzymes, while high molecular weight tannins cannot penetrate to bacterial proteins, causing lower toxicity to methanogens [55]. The anti-methanogenic 
effect of CT may be attributed to the direct inhibitory effect on methanogens, depending on the chemical structure of CT and methanogen species $[11,56]$. The anti-methanogenic activities of tannins may involve tannin action on functional proteins (enzymes) at accessible sites in or on methanogens [57].

Most studies conducted so far support the anti-methanogenic effects of tannins in the rumen. The decrease in $\mathrm{CH}_{4}$ production due to supplementation of tannins had been reported by many researchers [11-13,53,58-61]. On the contrary, some researchers reported that tannins did not show any effect on methanogenesis or even enhanced $\mathrm{CH}_{4}$ production in sheep [47]. Such discrepancies could be the result of doses, types and sources of tannins and types of diets. However, several studies have indicated that tannins have anti-methanogenic activity, either by direct inhibition of methanogens or indirectly through inhibition of protozoa [1114,46]. The effects of tannins on rumen feed fermentation, digestibility, and methane production were reviewed in Table $1 \& 2$.

Table 1: Effect of tanninsor their extracts on rumen $\mathrm{CH}_{4}$ production and fermentation parameters in-vitro.

\begin{tabular}{|c|c|c|c|c|c|}
\hline Tannin Sources & Level of Inclusion & $\begin{array}{l}\text { Feed Used in the } \\
\text { Study }\end{array}$ & $\begin{array}{l}\text { Effect on } \mathrm{CH}_{4} \\
\text { (Decrease) }\end{array}$ & $\begin{array}{l}\text { Effect on Digestion and } \\
\text { Fermentation Parameters }\end{array}$ & Sources \\
\hline Acacia angustissima & $20 \%$ of substrate & Brachiaria grass & $12.30 \%$ & Digestibility unaffected & Zeleke et al. (2006) \\
\hline Acacia mangium & $20 \%$ of substrate & Elephant grass & $28.90 \%$ & $\begin{array}{l}\text { Digestibility, TVFA \& protozoa } \\
\text { numbers unaffected }\end{array}$ & $\begin{array}{l}\text { Hariadi \& Santoso } \\
\qquad(2010)\end{array}$ \\
\hline $\begin{array}{l}\text { Biophytum } \\
\text { petersianum }\end{array}$ & $20 \%$ of substrate & Elephant grass & $25 \%$ & $\begin{array}{l}\text { Digestibility, TVFA \& protozoa } \\
\text { numbers unaffected }\end{array}$ & $\begin{array}{l}\text { Hariadi \& Santoso } \\
\qquad(2010)\end{array}$ \\
\hline Castanea sativa & 0.5 and $2.5 \mathrm{gkg}^{-1} \mathrm{DM}$ & $\begin{array}{l}\text { Grass silage and hay: } \\
\text { barley }(77: 23)\end{array}$ & $2.6-13.3 \%$ & $\begin{array}{c}\text { Digestibility, TVFA, A: P, protozoa } \\
\text { \& total bacterial numbers } \\
\text { unaffected }\end{array}$ & Sliwinski et al. [47] \\
\hline Chestnut tannins & $1-10 \%$ & Soybean & $5.1-33.3 \%$ & No information & Roth et al. [92] \\
\hline Emblica officinalis & $\begin{array}{l}0.5 \mathrm{ml} \text { per } 0.2 \mathrm{~g} \\
\text { substrate }\end{array}$ & $\begin{array}{l}\text { Wheat straw: } \\
\text { concentrate }(1: 1)\end{array}$ & 20 and $27.7 \%$ & $\begin{array}{c}\text { TVFA, A: P \& digestibility } \\
\text { unaffected, protozoa numbers } \\
\text { decreased }\end{array}$ & Patra et al. [14] \\
\hline Jatropa curcas & $20 \%$ of substrate & Elephant grass & $22.40 \%$ & $\begin{array}{l}\text { Digestibility, TVFA \& protozoa } \\
\text { numbers unaffected }\end{array}$ & $\begin{array}{l}\text { Hariadi \& Santoso } \\
\qquad(2010)\end{array}$ \\
\hline Lotus corniculatus & As sole diet & Itself & $29.70 \%$ & TVFA unaffected, A: P increased & $\begin{array}{l}\text { Tavendale et al. } \\
\text { (2005) }\end{array}$ \\
\hline Mimosa tannins & $1-10 \%$ & Soybean & $7.7-30.8 \%$ & No information & Roth et al. [92] \\
\hline Populus deltoides & $50.0-150 \mathrm{~g} \mathrm{~kg}^{-1} \mathrm{DM}$ & $\begin{array}{l}\text { Wheat straw: } \\
\text { concentrate }(1: 1)\end{array}$ & $14.6-21.5 \%$ & $\begin{array}{c}\text { TVFA, A: P \& protozoal numbers } \\
\text { unaffected }\end{array}$ & Patra et al. [11] \\
\hline Psidium guajava & $20 \%$ & Elephant grass & $18.40 \%$ & $\begin{array}{c}\text { Digestibility \& protozoal } \\
\text { numbers decreased, TVFA } \\
\text { unaffected }\end{array}$ & $\begin{array}{l}\text { Hariadi \& Santoso } \\
\qquad(2010)\end{array}$ \\
\hline Quebracho tannins & $10-20 \mathrm{gkg}^{-1} \mathrm{DM}$ & Wheat grass & $24.6-51.1 \%$ & Digestibility decreased & Min et al. [60] \\
\hline Quebracho tannins & $5-25 \%$ of substrates & $\begin{array}{c}\text { Timothy hay: } \\
\text { concentrate (65:35) }\end{array}$ & $12.9-38.2 \%$ & $\begin{array}{c}\text { Digestibility, TVFA \& methanogen } \\
\text { numbers decreased; A: P } \\
\text { unaffected }\end{array}$ & Bhatta et al. [12] \\
\hline Sesbania grandifora & $20 \%$ & Elephant grass & $9.20 \%$ & $\begin{array}{c}\text { Digestibility, TVFA and protozoal } \\
\text { numbers unaffected }\end{array}$ & $\begin{array}{l}\text { Hariadi \& Santoso } \\
\qquad(2010)\end{array}$ \\
\hline Sesbania sesban & $20 \%$ of substrate & Brachiaria grass & $37.40 \%$ & Digestibility unaffected & Zeleke et al. (2006) \\
\hline $\begin{array}{l}\text { Terminalia belerica } \\
\text { seed pulp extracts }\end{array}$ & $\begin{array}{l}0.5-30 \mathrm{ml} \text { of } 0.2 \mathrm{~g} \\
\text { substrate }\end{array}$ & $\begin{array}{l}\text { Wheat straw: } \\
\text { concentrate }(1: 1)\end{array}$ & $4.4-27.7 \%$ & $\begin{array}{l}\text { TVFA, digestibility, A: P and } \\
\text { protozoal numbers unaffected }\end{array}$ & Patra et al. [14] \\
\hline $\begin{array}{l}\text { Terminalia chebula } \\
\text { seed pulp }\end{array}$ & $\begin{array}{l}0.33^{-1} \mathrm{gl}^{-1} \text { or } 50- \\
150 \mathrm{gkg}^{-1} \mathrm{DM}\end{array}$ & $\begin{array}{l}\text { Wheat straw: } \\
\text { concentrate }(1: 1)\end{array}$ & $10.6-25.5 \%$ & $\begin{array}{l}\text { TVFA, A: P and protozoal } \\
\text { numbers unaffected }\end{array}$ & Patra et al. [14] \\
\hline Persea americana & $20 \%$ & Elephant grass & $11.80 \%$ & $\begin{array}{c}\text { Digestibility, TVFA \& protozoal } \\
\text { numbers unaffected }\end{array}$ & $\begin{array}{l}\text { Hariadi \& Santoso } \\
\qquad(2010)\end{array}$ \\
\hline
\end{tabular}


Table 2: Effect of tanninsor its extracts on rumen $\mathrm{CH}_{4}$ production and fermentation parameters in vivo.

\begin{tabular}{|c|c|c|c|c|c|c|}
\hline Tannin Sources & $\begin{array}{l}\text { Study Condition/ } \\
\text { Animals used }\end{array}$ & $\begin{array}{l}\text { Level of } \\
\text { Inclusion }\end{array}$ & $\begin{array}{l}\text { Feed Used in the } \\
\text { Study }\end{array}$ & $\begin{array}{c}\text { Effect on } \mathrm{CH}_{4} \\
\text { (Decrease) }\end{array}$ & $\begin{array}{l}\text { Effects on Other } \\
\text { Fermentation Parameters }\end{array}$ & $\begin{array}{l}\text { Sources or } \\
\text { References }\end{array}$ \\
\hline Acacia Mearnsii & Sheep & $\begin{array}{l}41 \mathrm{gkg}^{-1} \text { diets } \\
\text { (extract) }\end{array}$ & $\begin{array}{c}\text { Mixture of } \\
\text { ryegrass and } \\
\text { lucerne }(1: 1)\end{array}$ & $9.90 \%$ & $\begin{array}{c}\text { Digestibility, TVFA \& } \\
\text { total protozoa numbers } \\
\text { unaffected, A: P decreased }\end{array}$ & Carulla et al. [59] \\
\hline Acacia Mearnsii & Cattle & $\begin{array}{c}8.6 \text { and } 14.6 \mathrm{gkg}- \\
{ }^{1} \mathrm{DM}\end{array}$ & $\begin{array}{l}\text { Grazing rye grass } \\
\text { pasture with } 4.5 \\
\text { kg grain }\end{array}$ & 117.1 and $30 \%$ & Digestibility decreased & $\begin{array}{l}\text { Grainger et al. } \\
\text { [53] }\end{array}$ \\
\hline $\begin{array}{l}\text { Hedysarum } \\
\text { coronarium }\end{array}$ & Dairy cows & As sole feed & Rye grass pasture & $2.35 \%$ & No information & $\begin{array}{c}\text { Woodward et al. } \\
\text { [58] }\end{array}$ \\
\hline Lespedeza cuneata & Goats & As sole feed & L. cuneata & $51.40 \%$ & $\begin{array}{l}\text { Digestibility \& protozoa } \\
\text { numbers decreased TVFA } \\
\text { \&A: P unaffected }\end{array}$ & $\begin{array}{l}\text { Animut et al. } \\
{[11]}\end{array}$ \\
\hline Lespedeza cuneata & Goats & As sole diet & $\begin{array}{l}\text { In pasture of } \\
\text { crabgrass/tall } \\
\text { fescue }\end{array}$ & $30.20 \%$ & TVFA \& A: P unaffected & $\begin{array}{c}\text { Puchala et al. } \\
\text { [61] }\end{array}$ \\
\hline Lespedeza striata & Goats & $33-100 \%$ & $\begin{array}{l}\text { sorghum- } \\
\text { sudangrass }\end{array}$ & $32.9-58.4 \%$ & $\begin{array}{c}\text { Digestibility \& protozoal } \\
\text { numbers decreased, TVFA } \\
\text { \&A: P unaffected }\end{array}$ & $\begin{array}{l}\text { Animut et al. } \\
{[11]}\end{array}$ \\
\hline $\begin{array}{c}\text { Lotus } \\
\text { pedunculatus }\end{array}$ & Sheep & As sole feed & $\begin{array}{l}\text { In ryegrass \& } \\
\text { lucerne pasture }\end{array}$ & No effect & & $\begin{array}{c}\text { Woodward et al. } \\
{[26]}\end{array}$ \\
\hline $\begin{array}{l}\text { Quebracho } \\
\text { tannins }\end{array}$ & Beef cattle & $\begin{array}{l}10-20 \mathrm{gkg}^{-1} \text { of } \\
\mathrm{DM}\end{array}$ & $\begin{array}{l}\text { Barley silage, } \\
\text { barley grain and } \\
\text { rye grass mixture }\end{array}$ & No effect & $\begin{array}{c}\text { No effect on digestibility; } \\
\text { TVFA decreased; A: P } \\
\text { decreased }\end{array}$ & $\begin{array}{l}\text { Beauchemin et } \\
\text { al. [77] }\end{array}$ \\
\hline
\end{tabular}

Effects of tannins on feed intake, digestion and fermentation: The negative effects of high tannin concentration include reduced voluntary feed intake, reduced feed palatability, decreased digestion and development of conditioned aversions. Tannins affect intake by slowing down digestion and emptying the digestive tract, and stimulating the nervous system to inhibit further intake of feed. Loss of palatability could be a result of reactions between tannins and salivary muco-proteins, or a direct reaction with taste receptors, provoking an astringent sensation [62]. Consumption of low to moderate concentrations of tannins did not affect voluntary feed intake, while high tannin concentrations resulted in reduced intake [63].

Although many reports indicated negative effects of tannins, ruminants rely on tanniferous forages, which are usually high in $\mathrm{N}$ content, especially in tropical regions. The saliva of these ruminants is rich in proline protein, which binds to tannins, forming tanninproline-rich protein complexes $[64,65]$. The complexes are stable within a wide range of $\mathrm{pH}$ of the digestive tract, unlike other protein-tannin complexes [66]. In addition, ruminants have developed various adaptive mechanisms against the effects of tannins. Ruminants can benefit from dietary CT when the increases in protein flow from the rumen exceed the reduction in absorption of amino acids from the intestine. This is owing to the formation of tannin-proline-complexes, coupled with adaptive mechanisms developed by the microbes and the host animal. The ability of micro-organisms to degrade tannin-protein complexes is another important phenomenon that explains the utilization of tanniferous feeds by ruminants. There are Streptococcus species in the caecum [67] and entero-bacteria in the alimentary tracts of koalas [68] that are capable of degrading tannic-acid-protein complexes. Brooker et al. [69] have also isolated Streptococcus caprinus from feral goats that browse tannin-rich Acacia species with similar activity. In such scenarios, microbes may develop adaptive mechanisms to become resistant to adverse effects of tannins. For example, proteolytic bacteria that were initially sensitive to tannins were found to adapt after a short period of exposure by modifying their metabolism when tannin levels were not too high $[37,70]$.

Various findings have reported the effect of tannins on digestibility feeds. McSweeney noted that CT might increase the intestinal digestibility of organic matter. However, other authors reported a negative effect of tannins on feed digestion and nutrient absorption from the small intestine [17]. The explanations for the anti-nutritive nature of tannins included poor solubility of tanninprotein complexes in the abomasum, formation of tannin-digestiveenzyme complexes or new tannin-dietary-protein complexes and changes in intestinal absorption, due to the interaction of tannins with intestinal mucosa [71]. Tannins affect degradation of proteins in the rumen owing to their high affinity with proteins, as the ruminal $\mathrm{pH}$ is conducive to the formation of tannin-protein complexes [62]. The reduction in protein degradation is associated with a lower production of ammonia-N and a greater non-ammonia nitrogen flow to the duodenum. The effect of tannins on protein degradation is a reduction in the immediately degradable fraction and fractional rate of degradation [72-74]. Though tannins exert their negative effects mainly on proteins, they have negative effects on carbohydrates, particularly hemicellulose, cellulose, starch and pectins $[50,75]$. 


\section{Application of tannins in ruminant feeding}

Addition of quebracho tannins up to $1.5 \mathrm{gkg}-1 \mathrm{BW}$ in the diets of sheep did not affect feed intake, but decreased $\mathrm{CH}_{4}$ production [76]. Beauchemin et al. [77] also reported that inclusion of quebracho CT up to $2 \%$ of DM had no influence on feed intake in cattle. On the other hand, inclusion of quebracho tannins at $8.93 \%$ of DM in a diet of sheep reduced feed intake. In the study of Carulla et al. [59], feed intake in sheep was enhanced when an Acacia Mearnsii tannin extract was included in the diet, while $\mathrm{CH}_{4}$ emissions were suppressed, which is an important aspect for the practical application of tannins in animal diets. It is generally suggested that condensed tannin concentrations of more than $5 \%$ in diets may have adverse effects on nutrient utilization and productivity of animals, though the response depends on the types of tannin. In other studies, digestibility was not affected and $\mathrm{CH}_{4}$ production was reduced by inclusion of tannin extracts from Terminalia belerica [14], Acacia Mearnsii [59], Quebracho tannins [12] in the diet of ruminants. Other reported beneficial effects of tannins are protection of protein from degradation in the rumen, thereby increasing metabolizable protein supply to the duodenum, preventing bloat and increasing conjugated linoleic acid concentrations in ruminantderived foods. However, tannins exert an anti-microbial action on microbial growth, including cellulolytic bacteria and fungi, which may adversely affect fibre utilization. Inclusion of quebracho tannins at a dosage of $22.5 \mathrm{gkg}-1 \mathrm{DM}$ to lucerne hay decreased the fibre digestibility, whereas no effect was noted at dosages of 7.5 and 15g CT kg-1 DM. It has been proposed that higher concentrations of tannins in diets, which remain free after binding with proteins, may depress fibre digestion. This occurs through complexion with ligno-cellulose, thus preventing microbial digestion or by directly inhibiting cellulolytic micro-organisms and activities of fibrolytic enzymes or both.

The responses of tannins on concentrations of TVFA are not conclusive, with some researchers reporting no effect $[11,14,61]$, while others reported decreased concentrations [53,60,77], depending on dose and source [12]. There is some evidence that a significant decrease in methanogenesis could be possible without a considerable reduction of TVFA concentration and digestibility $[12,59]$, and such interventions needs to be tested further to refine the technology for practical application under field conditions.

\section{Conclusion}

It is possible to obtain substantial decrease in methane production with the inclusion tannin rich browses in ruminant diets but this is achieved not without compromising production especially with high tannin levels. Although there is a decrease in rumen protein degradability, there is an increase in post-rumen protein availability due to partitioning of excreted nitrogen more towards faeces and lesser towards urine. This in general can increase in efficiency of microbial protein synthesis and might make the use of tannins attractive significant in ruminant nutrition. The higher the number of hydroxyl groups in tannin structure, the higher the potential methane reduction [78-86].
Thus hydrolysable tannins appear to decrease methane production through inhibition of the growth and/or activity of methanogens- and/or hydrogen-producing microbes, and methane production per unit organic matter is digested to a greater extent than condensed tannins that decrease methane more through reduction in fibre digestion. Since the effects of tannins are a function of their nature, which varies from source to source, a systematic evaluation is needed to determine optimum levels of supplementation in a mixed diet in order to attain a maximal depressing effect on enteric $\mathrm{CH} 4$ production with a minimal detrimental effect on rumen fermentation of poor quality roughage based diet. Therefore, more in-vivo studies for tannin rich plants and their extract should be conducted with hydrolysable tannins since they appear to be more promising [86-94].

\section{Acknowledgement}

The authors would thank the University of Pretoria for financing the first author with bursary during the review of this work.

\section{References}

1. UN (2010) World Population Prospects: The 2010 Revision. Population Division of the Department of Economic and Social Affairs of the United Nations Secretariat, pp. 1-481.

2. Thornton PK, Gerber P (2010) Climate change and the growth of the livestock sector in developing countries. Mitigation and Adaptation Strategy for Global Change 15(2): 169-184.

3. Ajayi DA, Adenaye JA, Ajayi FT (2005) Intake and nutrient utilization of West African dwarf goats fed Mango (Mangifera indica), Ficus (Ficus thionningii), Gliricidia (Gliricidia sepium) forages and concentrates as supplements of basal diet of Guinea grass (Panicum maximum). World Journal of Agricultural Sciences 1(2): 184-189.

4. Mendieta-AB, Spörndly E, Reyes-SN, Norell L, Sporndly R (2009) Silage quality when Moringa oleifera is ensiled in mixtures with elephant grass, sugar cane and molasses. Grass and Forage Science 64(4): 364-373.

5. Ondiek JO, Abdulrazak SA, Tuitoek JK, Bareeba FB (1999) The effects of Gliricidia sepium and maize brand as supplementary feed to Rhodes grass hay on intake, digestion and live weight of dairy goats. Livestock Production Science 61(1): 65-70.

6. FAO (2011) Successes and failures with animal nutrition practices and technologies in developing countries. Makkar HPS, Rome.

7. Steinfeld H, Gerber P, Castel V, Rosales M, de Haan C (2006) Livestock's Long Shadow. Environmental Issues and Options. FAO, Rome, Italy.

8. Kirschke S, Bousquet P, Ciais P, Saunois M, Canadell JG, et al. (2013) Three decades of global methane sources and sinks. Nature Geoscience 6: 813-823.

9. Herrero M, Thornton P K, Kruska R L, Reid RS (2008) The spatial distribution of methane emissions from African domestic ruminants to 2030. Agriculture, Ecosystems and Environment 126: 122-137.

10. Tolera AK, Khazaal ER, Ørskov ER (1997) Nutritive evaluation of some browses species. Animal Feed Science and Technology 69: 143-154.

11. Animut G, Puchala R, Goetsch AL, Patra AK, Sahlu T, et al. (2008) Methane emission by goats consuming different sources of condensed tannins. Animal Feed Science and Technology 144: 228-241.

12. Bhatta R, Uyeno Y, Tajima K, Takenaka A, Yabumoto Y, et al. (2009) Difference in the nature of tannins on in-vitro ruminal methane and volatile fatty acid production and on methanogenic archaea and protozoal populations. J Dairy Sci 92(11): 5512-5522. 
13. Jayanegara A, Togtokhbayar N, Makkar HPS, Becker K (2009) Tannins determined by various methods as predictors of methane production reduction potential of plants by an in vitro rumen fermentation system. Animal Feed Science and Technology 150: 230-238.

14. Patra AK, Kamra DN, Agarwal N (2006) Effect of plant extracts on in vitro methanogenesis, enzyme activities and fermentation of feed in rumen liquor of buffalo. Animal Feed Science and Technology 128(3-4): 276291.

15. Beauchemin KA, Kreuzer M, O’Mara F, McAllister TA (2008) Nutritional management for enteric methane abatement: a review. Animal Production Science 48(2): 21-27.

16. McDonald P, Edwards R, Greenhalgh JFD, Morgan CA, Sinclair LA, et al. (2011) Animal nutrition. ( $7^{\text {th }}$ edn), Harlow, Pearson education, Prentice Hall, England.

17. Kamra DN (2005) Rumen microbial ecosystem. Current Science 89(1): $124-135$

18. Hobson PN (1989) The Rumen Microbial Eco-system. Elsevier Applied Science, London, UK.

19. Cieslak A, Szumacher-SM, Stochmal A, Oleszek W (2013) Plant components with specific activities against rumen methanogens. Animal 7(2): 253-265.

20. Niwińska B (2012) Digestion in Ruminants, CarbohydratesComprehensive Studies on Glycobiology and Glycotechnology. Chuan-FC (Eds.), In Tech.

21. Martin C, Morgavi DP, Doreau M (2009) Methane mitigation in ruminants: from microbe to the farm scale. The Animal Consortium 4(3): 351-365.

22. Miller TL (1995) Ecology of methane production and hydrogen sinks in the rumen. In: Engelhardt WV, Leon HMS, Breves G, et al. (Eds.) Ruminant Physiology: Digestion, Metabolism, Growth and Reproduction, Ferdinand Enke Verlag, Stuttgart, Germany, pp. 317-331.

23. Kobayashi Y (2010) Abatement of Methane Production from Ruminants: Trends in the manipulation of Rumen Fermentation. Asian-Australian Journal of Animal Science 23(3): 410-416.

24. Bayat A, Shingfield KJ (2012) Overview of nutritional strategies to lower enteric methane emission in ruminants. Agricultural Science Day, pp. $1-7$

25. Waghorn GC, Tavendale MH, Woodfield DR (2002) Methanogenesis in forages fed to sheep. Proceedings of New Zealand Grassland Association 64: $167-171$

26. Woodward SL, Waghorn GC, Laboyrie PG (2004) Condensed tannins in birdsfoot trefoil (Lotus corniculatus) reduce methane emissions from dairy cows. Proceedings of NZ Grassland Association 64: 160-164.

27. Hristov AN, Oh J, Firkins JL, Dijkstra J, Kebreab E, et al. (2013) Mitigation of methane and nitrous oxide emissions from animal operations: II. A review of manure management mitigation options. Journal of Animal Science 91(11): 5070-5094.

28. Takahashi J (2006) Emission of GHG from livestock production in Japan In: Soliva CR, Takahashi J and Kreuzer M (Eds.), Greenhouse Gases and Animal Agriculture: An Update, Elsevier, Amsterdam: Netherlands, pp. $1-20$.

29. Kumar R, Kamra DN, Agrawal N, Chaudhary LC (2009) Effect of eucalyptus (Eucalyptus globulus) oil on in vitro methanogenesis and fermentation of feed with buffalo rumen liquor. Animal Nutrition Feed and Technology 9(2): 237-243.

30. Blaxter KL, Clapperton JL (1965) Prediction of the amount of methane produced by ruminants. British Journal of Nutrition 19(4): 511-522.

31. Boadi D, Benchaar C, Chiquette J, Massé D (2004) Mitigation strategies to reduce enteric methane emissions from dairy cows: Update review. Canadian Journal of Animal Science 84(3): 319-335.
32. Hegarty RS, Alcock D, Robinson DL, Goopy JP, Vercoe PE (2010) Nutritional and flock management options to reduce methane output and methane per unit product from sheep enterprises. Animal Production Science 50(12): 1026-1033.

33. Van Soest PJ (1994) Nutritional Ecology of the Ruminant. ( $2^{\text {nd }}$ edn $)$ Comstock Publishing Associates/Cornell University Press, Ithaca, NY, USA.

34. Takahashi J (2011) Some Prophylactic Options to Mitigate Methane Emission from Animal Agriculture in Japan. Asian-Australian Journal of Animal Science 24(2): 285-294

35. Santoso B, Kume S, Nonaka K, Kimura K, Mizokoshi H, et al. (2003) Methane emission, nutrient digestibility, energy metabolism and blood metabolites in dairy cows fed silages with and without galactooligosaccharides supplementation. Asian-Australian Journal of Animal Science 16(4): 534-540.

36. Hindrichsen IK, Kreuzer M, Machmuller A, Bach Knudsen KE, Madsen J, et al. (2003) Methane release and energy expenditure of dairy cows fed concentrates characterized by different carbohydrates. In: Souffrant WM and Metges CC (Eds.), Proceedings of the EAAP-Symposium on Energy and Protein Metabolism and Nutrition, Academic Publisher Wageningen: The Netherlands, pp. 413-416.

37. Jones GA, McAllister TA, Muir AD, Cheng KJ (1994) Effects of sainfoin (Onobrychis viciifolia Scop.) condensed tannins on growth and proteolysis by four strains of ruminal bacteria. Appl Env Microbiol 60(4): 1374-1378.

38. Arthington JD, Brown WF (2005) Estimation of feeding value of four tropical forage species at two stages of maturity. Journal of Animal Science 83(7): 1726-1731.

39. Johnson KA, Johnson DE (1995) Methane emissions from cattle. Journal of Animal Science 73(8): 2483-2492.

40. Lovett D, Lovel LS, Stack L, Callan J, Finlay M, et al. (2003) Effect of forage concentrate ratio and dietary coconut oil level on methane output and performance of finishing beef heifers. Livestock Production Science 84(2): $135-146$

41. Agle M, Hristov AN, Zaman S, Schneider C, Ndegwa P, et al. (2010) Effects of ruminally degraded protein on rumen fermentation and ammonia losses from manure in dairy cows. Journal of Dairy Science 93(4): 16251637.

42. Bannink A, France J, Lopez S, Gerrits WJJ, Kebreab E, et al. (2008) Modelling the implications of feeding strategy on rumen fermentation and functioning of the rumen wall. Animal Feed Science and Technology 143: 3-26.

43. Sauvant D, Giger-RS, Serment A, Broudiscou I (2011) Influences des régimes et de leur fermentation dans le rumen sur la production de méthane par les ruminants. In: Doreau M, Baumont R, and Perez JM (Eds.), Gaz à effet de serre en élevage bovin: Le méthane. (In French.). INRA Productions Animales 24(5): 433-446.

44. Boland TM, Hart KJ, Pierce KM, Lynch BM, McDonnel L R, et al. (2009) The effect of pre-grazing herbage mass on growth rate and methane emissions of grazing beef cattle. Journal of Dairy Science 92: 343-339.

45. McGeough EJ, O'ki ELYP, Hart KJ, Moloney AP, Boland TM, et al. (2010) Methane emissions, feed intake, performance, digestibility, and rumen fermentation of finishing beef cattle offered whole-crop wheat silages differing in grain content. Journal of Animal Science 88(8): 2703-2716.

46. Moss AR (2000) Methane production by ruminants: Its contribution to global warming. Annales of the Zootechnie 49(3): 231-253.

47. Sliwinski BJ, Kreuzer M, Wettstein HR, Machmuller A (2002) Rumen fermentation and nitrogen balance of lambs fed diets containing plant extracts rich in tannins and saponins and associated emissions of nitrogen and methane. Archives of Animal Nutrition 56(6): 379-392. 
48. Goel G, Makkar HPS, Becker K (2008) Effects of Sesbania sesban and Carduuspycno cephalus leaves and Fenugreek (Trigonellafoenumgraecum L.) seeds and their extracts on partitioning of nutrients from roughage-and concentrate-based feeds to methane. Animal Feed Science and Technology 147(1-3): 72-89.

49. Cottle DJ, Nolan JV, Wiedemann SG (2011) Ruminant enteric methane mitigation: a review. Animal Production Science 51(6): 491-514.

50. Schofield P, Mbugua DM, Pell AN (2001) Analysis of condensed tannins: a review. Animal Feed Science Technology 91(1-2): 21-40.

51. Mueller-HI (1999) Tannins: their nature and biological significance. In: Caygill JC, Mueller-HI (Eds.), Secondary plants products. Anti-nutritional and beneficial actions in animal feeding, Nottingham Univ Press, UK, pp. 17-70.

52. Patra AK, Kamra DN, Bhar R, Kumar R, Agarwal N (2011) Effect of Terminalia chebula and Allium sativum on in vivo methane emission by sheep. Journal of Animal Physiology and Animal Nutrition 95(2): 187191.

53. Grainger C, Clarke T, Auldist MJ, Beauchemin KA, McGinn SM, et al (2009) Potential use of Acacia mearnsii condensed tannins to reduce methane emissions and nitrogen excretion from grazing dairy cows. Canadian Journal of Animal Science 89(2): 241-251.

54. Jayanegara A, Winac E, Solivaa RC, Marquardta S, Kreuzera M, et al (2011) Dependence of forage quality and methanogenic potential of tropical plants on their phenolic fractions as determined by principal component analysis. Animal Feed Science and Technology 163: 231-243.

55. Field JA, Kortekaas S, Lettinga G (1989) The tannin theory of methanogenic toxicity. Biology of Wastes 29(4): 241-262.

56. Patra AK (2010) Meta-analyses of effects of phytochemicals on digestibility and rumen fermentation characteristics associated with methanogenesis. Journal of the Science of Food and Agriculture 90(15): $2700-2708$

57. Field JA, Lettinga G (1987) The methanogenic toxicity and anaerobic degradability of hydrolysable tannins. Water Research 21(3): 367-394.

58. Woodward SL, Waghorn GC, Lassey KR, Laboyrie PG (2002) Does feeding sulla (Hedysarum coronarium) reduce methane emissions from dairy cows. Proceedings of NZ Grassland Association 62: 227-230.

59. Carulla JE, Kreuzer M, Machmuller A, Hess HD (2005) Supplementation of Acacia mearnsii tannins decreases methanogenesis and urinary nitrogen in forage-fed sheep. Crop and Pasture Science 56(9): 961-970.

60. Min BR, Pinchak WE, Anderson RC, Fulford JD, Puchala R (2006) Effects of condensed tannins supplementation level on weight gain and in vitro and in vivo bloat precursors in steers grazing winter wheat. Journal of Animal Sciences 84(9): 2546-2554.

61. Min BR, Pinchak WE, Fulford JD, Puchala R (2005) Wheat pasture bloat dynamics, in vitro ruminal gas production, and potential bloat mitigation with condensed tannins. Journal of Animal Science 83: 1322-1331.

62. McLeord MN (1974) Plant tannins-Their role in forage quality. Nutrition Abstract Review 44: 803-812.

63. Barry TN, Duncan SJ (1984) The role of condensed tannins in the nutritional value of Lotus pedunculatus for sheep 1 . Voluntary intake. British Journal of Nutrition 51(3): 485-491.

64. Austin PJ, Suchar LA, Robbins CT, Hagerman AE (1989) Tannins-binding proteins in saliva of deer and their absence in saliva of sheep and cattle. Journal of Chemical Ecology 15(4): 1335-1347.

65. Foley WJ, Iason GR, McArthur C (1999) Role of secondary metabolites in the nutritional ecology of mammalian herbivores: How far have we come in 25 years? In: Jung HJG and Fahey GCJr (Eds.), Nutritional Ecology of Herbivores, Illinois, USA, pp. 130-209.

66. Hagerman AE, Butler LG (1989) Choosing appropriate methods and standards for assaying tannins. Journal of Chemical Ecology 15(6):
1795-1810

67. Osawa R, Mitsuoka T (1990) Selective medium for enumeration of tannin-protein complex-degrading Streptococcus spp. in feces of koalas. Applied Environment Microbiology 56(11): 3609-3611.

68. Osawa R (1992) Tannin-protein complex-degrading entero-bacteria isolated from the alimentary tracts of koalas and a selective medium for their enumeration. Applied Environmental Microbiology 58(5): 17541759 .

69. Brooker JD, O’Donovan LA, Skene I, Clarke K, Blackall L, et al. (1994) Streptococcus caprinus sp. nov., a tannin-resistant ruminalbacterium from feral goats. Letters in Applied Microbiology 18(6): 313-318.

70. O'Donovan L, Brooker JD (2001) Effect of hydrolysable and condensed tannins on growth, morphology and metabolism of Streptococcus gallolyticus (S. caprinus) and Streptococcus bovis. Microbiology 147(4): 1025-1033.

71. McNabb WC, Peters JS, Foo LY, Waghorn GC, Jackson SJ (1998) Effect of condensed tannins prepared from several forages on the in vitro precipitation of ribulose-1, 5-bisphospathe carboxilase (rubisco) protein and its digestion by trypsin (EC 2.4.21.4) and chymotrypsin (EC 2.4.21.1). Journal of the Science Food Agriculture 77(2): 201-212.

72. Aharoni Y, Gilboa N, Silanikove N (1998) Models of suppressive effect of tannins. Analysis of the suppressive effect of tannins on ruminal degradation by compartmental models. Animal Feed Science and Technology 71: 251-267.

73. Frutos P, Hervas G, Giraldez FJ, Fernandez M, Mantecon AR (2000) Digestive utilization of quebracho- treated soya bean meal in sheep. Journal Agricultural Science 134(1): 101-108.

74. Hervas G, Frutos P, Serrano E, Mantecon AR, Giraldez FJ (2000) Effect of tannic acid on rumen degradation and intestinal digestion of treated soya bean meals in sheep. Journal of Agricultural Science 135(3): 305310.

75. Chiquette J, Cheng KJ, Costerton JW, Milligan LP (1988) Effect of tannins on the digestibility of two isosynthetic strains of birds foot trefoil (Lotus corniculatusL.) using in vitro and insacco techniques. Canadian Journal of Animal Science 68(3): 751-760.

76. Hervas G, Perez V, Giraldez FJ, Mantecon AR, Almar MM, et al. (2003) Intoxication of sheep with quebracho tannin extract. J Compar Pathol 129(1): 44-54.

77. Beauchemin KA, McGinn SM, Martinez TF, McAllister TA (2007) Use of condensed tannin extract from quebracho trees to reduce methane emissions from cattle. J Anim Sci 85(8): 1990-1996.

78. Azzaz HH, Kholif AM, Murad HA, Hanfy MA, Abdel GMH (2012) Utilization of cellulytic enzymes to improve the nutritive value of banana waste and performance of lactating goats. Asian Journal of Animal and Veterinary Advances 7(8): 664-673.

79. Beauchemin KA, Holtshausen L (2011) Developments in enzyme usage in ruminants. In: Bedford MR and Partridge GG (Eds.), Enzymes in Aarm Animal Nutrition (2 ${ }^{\text {nd }}$ edn), CABI Bodmin, UK, pp. 206-230.

80. Hatfield RD, Ralph J, Grabber JH (1999) Cell wall structural foundations: Molecular basis for improving forage digestibilities. Crop Science 39(1): 27-37.

81. Huhtanen P, Rinne M, Nousiainen J (2009) A meta-analysis of feed digestion in dairycows. 1 . The effects of forage and concentrate factors on total diet digestibility. Journal of Dairy Science 92(10): 5019-5030.

82. Kamra DN, Agarwal N, Chaudhary LC (2006) Inhibition of ruminal methanogenesis by tropical plants containing secondary compounds. International Congress Series 1293: 156-163.

83. Kingston-SAH, Edwards JE, Huws SA, Kim EJ, Abberton M (2010) Plant based strategies towards minimizing 'livestock's long shadow' Proceeding Nutrition Society 69(4): 613-620. 
84. Krueger NA, Adesogan AT, Staples CR, Krueger WK, Kim SC, et al. (2008) Effect of method of applying fibrolytic enzymes or ammonia to Bermuda grass hay on feed intake, digestion and growth of beef steers. J Anim Sci 86(4): 882-889.

85. Linington MJ (1990) The use of Sanga cattle in beef production. In: Technical communication, Department of Agriculture: South Africa, pp. 31-37.

86. McAllister TA, Hristov AN, Beauchemin KA, Rode LM, Cheng KJ (2001) Enzymes in ruminant diets. In: Bedford MR and Partridge GG (Eds.), Enzymes in Farm Animal Nutrition, CABI publishing, Wallingford, Oxon, UK, pp. 273-298.

87. McGinn SM, Beauchemin KA, Coates T, Colombatto D (2004) Methane emissions from beef cattle: Effects of monensin, sunflower oil, enzymes, yeast, and fumaric acid. J Anim Sci 82(11): 3346-3356.

88. Minson DJ (1990) Forage in ruminant nutrition. Academic press, London, UK, pp. 483.

89. Mirzaei-AA, Meheri-SN (2011) Factors affecting mitigation of methane emission from ruminants I: Feeding Strategies. Asian Journal of Animal and Veterinary Advances 6(9): 888-908.
90. Moss AR, Givens DI, Gransworthy PC (1995) The effect of supplementing grass silage with barley on digestibility, in sacco degradability, rumen fermentation and methane production in sheep at two levels of intake. Animal Feed Science and Technology 55: 9-33.

91. Pelletier N, Pirog R, Rasmussen R (2010) Comparative life cycle environmental impacts of three beef production strategies in the Upper Midwestern United States. Agricultural Systems 103: 380-389.

92. Roth S, Steingass H, Drochner W (2002) Reduction of methane emissions and optimization of $\mathrm{N}$ feed for ruminants through the treatment of feed with tannins. In: Bocker R (Eds.), Globale Klimaerwarmung und Ernahrungs sicherung, Hohenheim Environmental Conference, publishing Gunter Heimbach 34: 181-184.

93. Sauvant D, Giger RS (2009) Modélisation des interactions digestives et de la production de méthane chez les ruminants (In French). INRA Productions Animales 22(5): 375-384.

94. Tamminga S, Brandsma GG, Dijkstra J, Vanduinkerken G, Van VAM, et al. (2007) Protein Evaluation for Ruminants: The DVE/OEB 2007 System. CVB Documentation report nr. 53. Lelystad, The Netherlands: Centraal Veevoederbureau, pp. 1-61. 